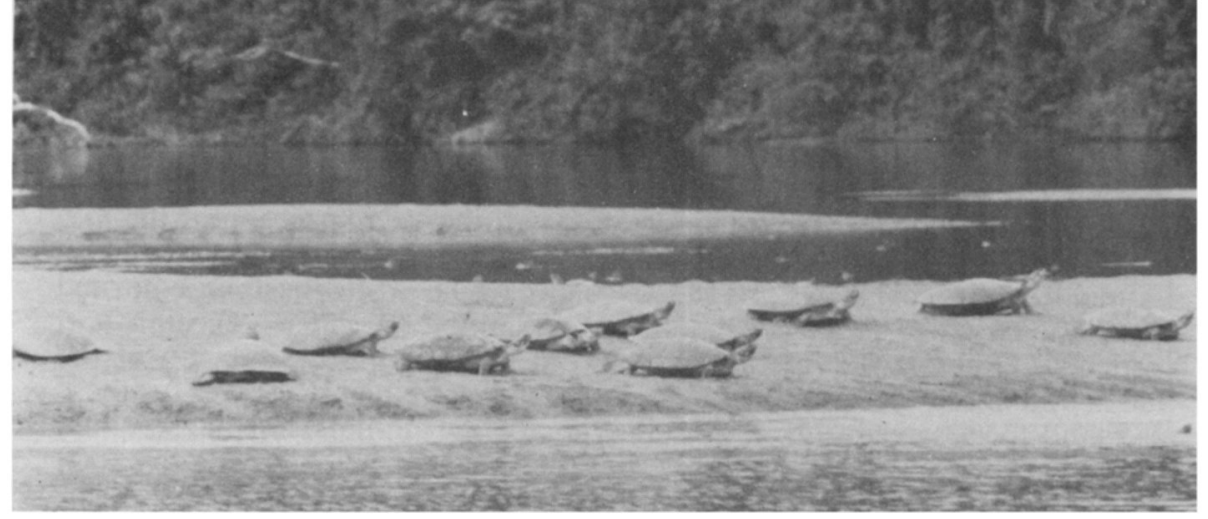

\title{
South America's River Turtles: Saving Them by Use
}

\section{Russel/ A. Mittermeier}

The seven species of Podocnemis river turtles, in northern South America, have long been important sources of meat for local people; as such they have many advantages over both native mammals and imported domestic species. But most of the populations are now severely depleted, and several species are endangered. The author suggests that if nesting beaches were effectively protected these turtles would recover their numbers, and this, combined with careful management and sustained-yield cropping, would ensure their survival as a valuable resource.

The idea is slowly gaining ground that in some parts of the world wild game animals, harvested on a sustained yield basis, can produce more protein than cattle or other domestic animals, especially in tropical countries where the domestic animals often adapt poorly. This is sound evolutionary thinking, for an array of native tropical species that has developed in situ over millions of years is more likely to be suited to make maximum use of available resources than are one or two imported domestic species selectively bred by man, of ten in a quite different environment. Many imported animals are able to use only a small part of the resources, and have little resistance to tropical diseases.

The tropical rain forests and rivers of the Amazon region of South America harbour many animals that could be important protein sources, including tapir Tapirus terrestris, capybara Hydrochoerus hydrochaeris, agoutis Dasyprocta spp., ${ }^{15}$ paca Agouti paca, Amazonian manatee Trichechus inunguis, peccaries Tayassu spp., armadillos Dasypus spp. and others, several kinds of deer Odocoileus virginianus and Mazama spp., iguanas Iguana iguana, two land tortoises Geochelone carbonaria and $G$. denticulata, and freshwater turtles, most notably those of the genus Podocnemis. None of these are regular items on US or European tables, but they have been staples in the diet of Amazonia's aboriginal inhabitants for centuries, and I can personally attest that their meat is superb and of ten equal or even superior to high-quality beef.

In Amazonia several South American governments, notably the Brazilian, have been experimenting with cattle-raising, as part of a large-scale programme to develop the Amazon region. This has been fairly successful along the várzea or flood plain of the main Rio Amazonas, where grass grows on 
fertile soils rejuvenated every year by nutrient-rich 'white water' silts flowing down from the Andes. But the várzea makes up only about two per cent of Amazonia ${ }^{8}$ and on most of the terra firme of Amazonia and in the igapó or swamp forests of the nutrient-poor 'black' water rivers, cattle-raising varies from moderately difficult to impossible, due to either highly impoverished soils or flooding throughout most of the year.

Farsightedly, the Brazilian, Venezuelan, Colombian and Peruvian governments are investigating the possibilities both of harvesting and managing native animal populations on a sustained-yield basis, and also of large-scale captive breeding and even domestication. And of all the native South American species, the Podocnemis turtles offer perhaps the greatest hope as a major, long-term, easy-to-manage natural resource. They have several advantages:

Abundance. Podocnemis turtles are still fairly abundant in many areas and occupy a profitable niche in Amazonia, although they have diminished tremendously after centuries of uncontrolled exploitation. In 1799 Humboldt estimated that there were more than a million female $P$. expansa nesting in the lower Orinoco alone. ${ }^{7}$

Number of offspring. Whereas tapir, manatee and domestic cow produce only one offspring at a time, these turtles, depending on species and size of female, produce anywhere from five to 150 eggs, of which a substantial proportion would survive if some attempt were made to control predation and other natural losses of eggs and juveniles. ${ }^{1}$ Some hatchlings could be captured as they leave the nest and kept in captivity until they reached $150-250 \mathrm{~mm}$, when they would no longer be vulnerable to most natural predators if released. Another small portion of each year's crop could be raised to adulthood under controlled conditions and used for captive breeding projects and/or for the market. But captive breeding needs further investigation, and it may be that careful management and cropping of natural populations would give better results than either captive breeding or domestication.

Feeding habits. These turtles feed largely on aquatic plants and fruits that fall into the waters of the flooded forests; they also scavenge dead fish and other animal matter. They are thus in no way competing with man, and can easily exist side by side with him provided they are rationally harvested on a sustained yield basis and not ruthlessly over-exploited. At the same time if captive breeding should prove to be useful they are fairly simple and inexpensive to rear on a diet of plant matter, discarded market produce, fish remains, slaughter-house leftovers, even viscera of previously butchered turtles, all otherwise useless to man. Raising 100 kilos of this turtle meat would require much less effort and expense than, for example, 100 kilos of beef or tapir.

Energy requirements. Turtles and other reptiles, being ectotherms, need less energy than mammals to maintain themselves. A resting mammal produces from three to ten times as much heat as a resting reptile just to keep its body temperature at the required level. ${ }^{18}$ This means that a mammal has to eat more just to keep alive, and also usually needs a larger living area. A Podocnemis turtle requires much less food than a mammal of similar size and more turtles could be raised per unit area.

Spatial requirements. Raising cattle in Amazonia requires expensive and destructive forest clearance, the cultivation of special food plants, and rela ted procedures. Raising pacas, agoutis, tapirs and other game species requires 
either large tracts of natural forest habitat (in which the animals are sparsely distributed) or large, specially constructed cages for captive breeding. (Capybaras are an exception. They can be raised at fairly high densities in some natural savannas and this is being done in Venezuela.) Podocnemis turtles, on the other hand, have few demands. Provided wild populations are given adequate protection, especially in the nesting season, and harvesting is done on a carefully calculated sustained yield system, these turtles could once again reach their former high densities without any environmental alteration. Captive breeding also requires little environmental alteration, for turtles can be kept in large cement tanks, ponds, or natural or man-made lakes at far higher densities than cattle. Smith ${ }^{16}$ estimates that a one-acre lake of $P$. expansa could produce approximately 440 times more meat per acre per year than a one-acre cattle pasture $(22,000 \mathrm{lb} /$ acre/year compared to $50 \mathrm{lb} /$ acre/year $)$.

Survival. Being reptiles, turtles are able to survive long periods of time without food. Some turtles, e.g. Sternotherus, can even lower their metabolism during periods of starvation, thus making whatever energy is available go much further, ${ }^{3}$ and Podocnemis may have this ability as well. They are certainly able to survive even severe seasonal food shortages and appear to be quite resistant to disease. Thus, transport and storage requirements of live specimens are less exacting than with mammals. Durability in captivity varies considerably from species to species, but the two most important species commercially, $P$. expansa and $P$. unifilis, are very hardy animals.

Growth Rate. Contrary to popular belief, turtles grow fairly quickly, although more slowly than domestic mammals. There is little data on this aspect of Podocnemis biology, but preliminary observations suggest that $P$. expansa reaches sexual maturity and marketable size at five to seven years of age; ${ }^{13,12}$ the smaller species may grow more rapidly.

By-products. It is possible that turtles may provide useful by-products, although more investigation is needed. Shells, which at present are discarded, might be employed as a bone-meal calcium supplement for cattle. Skulls, also discarded at present, could be sold to biological supply houses for use in schools and universities.

\section{Eight Podocnemis Species}

The Podocnemis are members of the turtle infraorder Pleurodira, the sidenecked turtles. These differ from the Cryptodira, the other living turtle infraorder, in a number of ways, most noticeably by retracting head and neck sideways into the shell, whereas Cryptodira pull them straight back. Pleurodire turtles are restricted to South America, Africa-Madagascar and Australia-New Guinea. Native North American and European turtles are all cryptodires, as are the sea turtles.

Within the Pleurodira, the Podocnemis are members of the family Pelomedusidae, subfamily Podocneminae. The genus Podocnemis consists of eight living species, seven in northern South America and one on Madagascar. The group is fairly well represented in the fossil record and extends as far back as the Cretaceous (Podocnemis elegans of Brazil). The fossil record is richest in Africa and it seems likely that the group originated there and later spread to South America ${ }^{20}$ Since some of the early Podocnemis were marine or estuarine forms, their dispersal from Africa to South America would have been relatively simple, especially as Africa and South America were closer during the Cretaceous and early Tertiary than today. ${ }^{20}$ 
We know very little about the biology of Podocnemis madagascariensis other than that it reaches a length of about $440 \mathrm{~mm}$. Our recent studies suggest that it is sufficiently distinct morphologically, karyotypically and biochemically to warrant recognition as a separate genus (Erymnochelys) within the subfamily Podocneminae.

Of the seven living South American forms, the best known is the giant South American river turtle $P$. expansa, one of the world's largest freshwater turtles, with a carapace length of up to $820 \mathrm{~mm}$ and weighing as much as 50 kilos. It occurs throughout Amazonia, in both the Amazon and Orinoco drainages, and in several rivers in Guyana. Nesting aggregations on glistening sand beaches, set against an imposing backdrop of verdant tropical forest, are among the most spectacular natural sights in South America. Nesting occurs in the months of lowest water, when beaches emerge. Each female digs out a nest and deposits 50-150 eggs, usually at night or in the early morning, although day nesting sometimes occurs. The eggs hatch in 45-50 days, and the baby turtles, only $40-60 \mathrm{~mm}$ long, after digging out of their nests, must race for their lives to the nearest water to escape the waiting avian predators - vultures Coragyps atratus and Cathartes aura, jabiru storks Jabiru mycteria, maguari storks Euxenura maguari, great blue herons Ardea herodias, crested caracaras Caracara plancus and others. The successful ones then have to contend with fish and reptile predators - piranhas Serrasalmus spp., large catfish Brachyplatystoma spp., and caimans Caiman crocodilus and Melanosuchus niger. A substantial proportion perishes at this stage. Roze ${ }^{14}$ estimated that only about 5 per cent survive more than a few hours.

In some years, there are also considerable losses due to unusually early rises in river levels and water infiltration into the nests. In 1973, for instance, all $P$. expansa nests in the Rio Trombetas, the largest known Brazilian nesting area, were inundated and destroyed before they hatched. At Playa del Medio in the Rio Orinoco in Venezuela, Ojasti estimated that 25-80 per cent of each year's crop of eggs is lost in this way. Sometimes, too, high humidity compacts the surface of the nests, making it impossible for the hatchlings to escape. ${ }^{12}$

Added to the natural dangers is the threat posed by man. For centuries, hatchlings from nests that escaped the egg-gatherers were captured for food. In the 1960 s a new demand for hatchlings suddenly arose as $P$. unifilis and $P$. expansa, and to a lesser extent several other species, became popular items in the pet trade, notably in the US. This trade has now been curtailed as all Podocnemis species are listed in Appendix II of the international trade convention (CITES). $P$. expansa and $P$. unifilis are also on the US Endangered Species List, and $P$. expansa is on the Colombian Endangered Species List.

Adult turtles have always been an important food source. A female $P$. expansa provides four to seven kilos of high quality meat that can feed a family for several days. ${ }^{12}$ In Brazilian Amazonia, at least ten different dishes are prepared from $P$. expansa and almost all edible parts of the animal are used. However, the increasing rarity of this turtle has sent the market price so high that the average Amazonian can no longer afford one. Fifty years ago, in Manaus, a large $P$. expansa cost the equivalent of US $1 c .^{16}$ Today, in some parts of Brazilian Amazonia, the price may be as much as US\$80 per turtle ${ }^{16}$ (pers. obs.). In Venezuela, a large female may cost $\$ 8$ in the larger cities. ${ }^{16}$

The yellow-spotted Amazon sideneck turtle Podocnemis unifilis is somewhat smaller. It is reported to reach $680 \mathrm{~mm}$ in length (Siebenrock, 1902), but a 
specimen of $440 \mathrm{~mm}$ weighing eight kilos is considered very large. Usually nesting alone or in small groups, this turtle is less particular about the nesting site than $P$. expansa, and may use sand beaches, muddy, clayey or sandy river banks, or even burned-over fields. The 15-41 eggs hatch in about the same time as $P$. expansa eggs. $P$. unifilis has perhaps the finest meat of all the Podocnemis and is unquestionably the hardiest in captivity. It is the most widely distributed member of the Podocneminae, and is heavily exploited throughout its range, which includes the Amazon and Orinoco drainages and several rivers in the Guianas.

A still smaller species is $P$. sextuberculata, which reaches $340 \mathrm{~mm}$ in carapace length and 3.5 kilos. It is found only in certain parts of the Amazon drainage, being particularly abundant in the Upper Amazon or Solimões and in a number of Lower Amazon tributaries. Like $P$. expansa it nests on sand beaches, but, although to some extent a social nester, it does not form the same huge nesting aggregations. The 6-22 eggs hatch in $45-50$ days. The young are characterised by six prominent swellings on the sides of the plastron or lower shell - hence the Latin name - which have usually disappeared by the time the animal is adult.

The red-headed Amazon side-neck P. erythrocephala is the smallest living member of the genus, rarely exceeding $300 \mathrm{~mm}$ or two kilos. It was formerly called $P$. cayennensis, but a recent study by the author indicated that this name is invalid. ${ }^{10}$ It is found primarily in the 'black water' Rio Negro system of Brazil, and also in the Casiquiare and the upper reaches of the Orinoco in southern Venezuela, and there are occasional isolated reports from other areas in Amazonia. The 5-14 eggs are usually laid on small, shrub- and grass-covered beaches, locally known as campinas. Juveniles and adult males have very attractive markings with bright red or reddish-orange colour patterns, which fade to dull brown in adult females. As it is not hardy in captivity this turtle probably will not be important in captive breeding projects, but natural populations, properly managed and harvested on a sustained yield basis, could continue to be a significant resource in the protein-poor Rio Negro region.

A little-known species restricted to the Rio Magdalena and Rio Sinú drainages in Colombia is Podocnemis lewyana. Similar in size to P. unifilis, reaching $480 \mathrm{~mm}$ in shell length and more than eight kilos, it lays 16-30 eggs on a variety of river bank substrata, but not on sand beaches.

Another small species is Podocnemis vogli, which reaches $330 \mathrm{~mm}$ and nearly four kilos. ${ }^{1}$ Found in the lakes, lagoons and creeks of the llanos, or plains, of Colombia and Venezuela, it is an important source of protein, and in some areas dogs are trained to hunt it during its nesting-season wanderings. A solitary nester, it lays 7-21 eggs.

$P$. dumeriliana is a large species, reaching $455 \mathrm{~mm}$ and over 13 kilos. Morphologically, karyotypically, biochemically and behaviourally it differs considerably from other South American Podocnemis and, like its Madagascan relative, deserves recognition as a separate genus (Peltocephalus) within the Podocneminae. The huge head and powerfully-beaked jaws bear a superficial resemblance to the alligator snapping turtle Macroclemys temmincki of the south-eastern United States, and the two may well occupy similar ecological niches. Like snapping turtles, this species is very aggressive, especially when freshly caught. Although it cannot lunge with the snapper's snake-like 


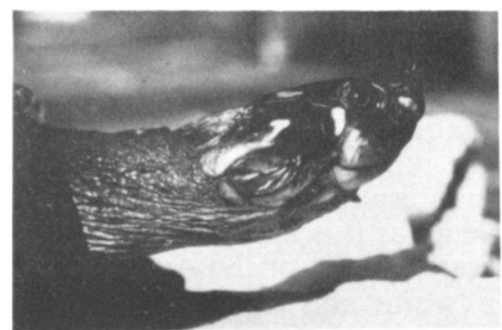

Male Podocnemis unifilis

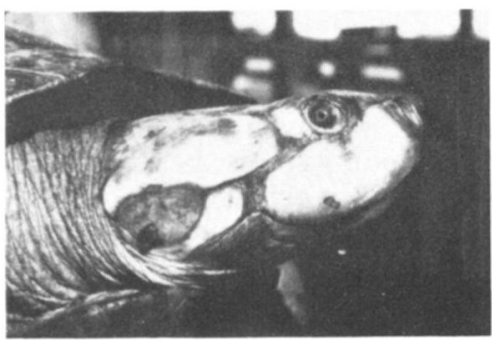

Female $P$. unifilis

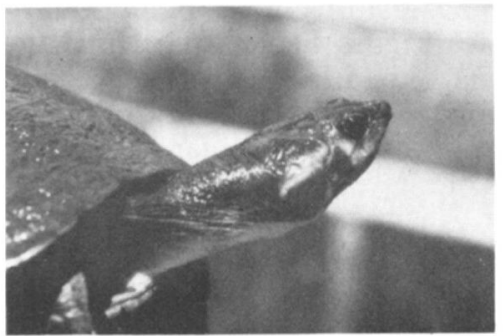

P. lewyana

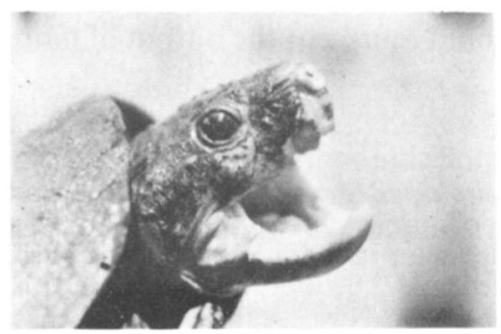

P. dumeriliana

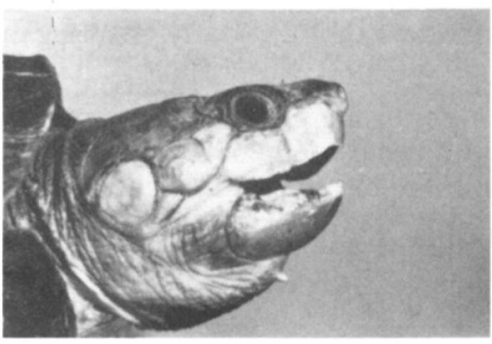

P. madagascariensis from Madagascar

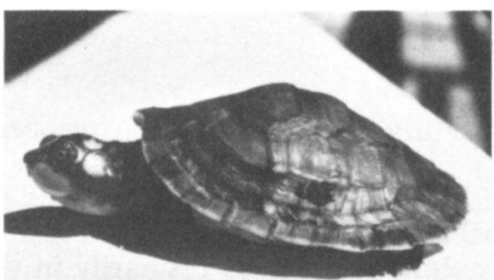

Juvenile $P$. expansa

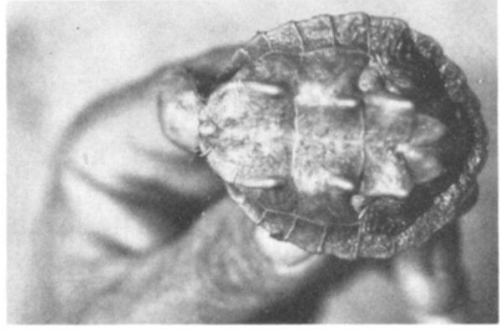

Hatchling $P$. tuberculata

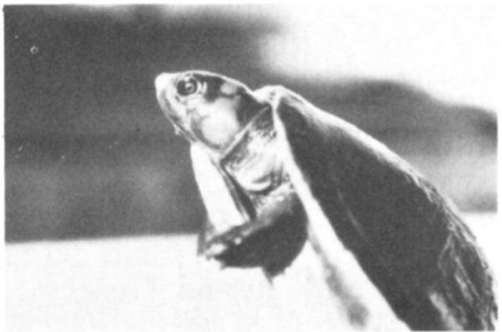

Juvenile $P$. erythrocephala

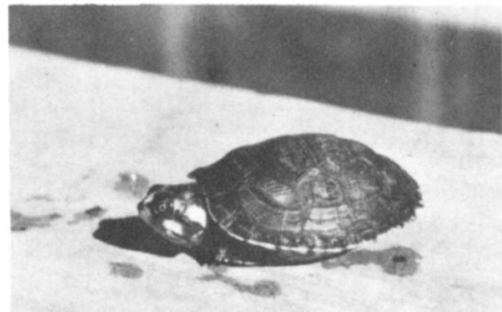

Juvenile $P$. vogli

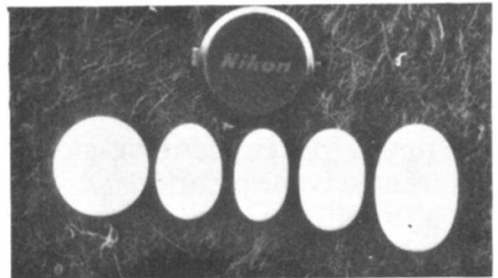

Eggs of, left to right, $P$. expansa, $P$ unifilis, $P$, ervthrocephala, $P$. sextuberculata and $P$. dumeriliana 
rapidity, it is held in great respect by the inhabitants of Amazonia. Little is known of its nesting habits, but local people report that it lays 7-25 eggs practically anywhere on dry land in the igapo forests, and sometimes on sand beaches. Since it does not nest in predictable areas it is a difficult animal to exploit. It is found primarily in the 'black water' rivers of the Amazon and Orinoco drainages, occasionally turns up in 'white' and 'clear' water rivers, and is most abundant in the 'black water' Rio Negro drainage. Fair numbers are caught each year in the Rio Negro on hook and line.

\section{Conservation and the Future}

The Podocnemis turtles have always been an important protein resource in Amazonia. They could become even more important, given careful management and sustained-yield harvesting of natural populations, perhaps combined with captive breeding if it proves feasible. But to achieve this -indeed, merely to restore these turtles to the level of importance they held in aboriginal times-strict conservation measures are essential, especially for nesting females and eggs. Uncontrolled exploitation has reduced them to the point at which all are now listed in the IUCN Red Data Book of Endangered Amphibia and Reptilia, and P. expansa is on a red sheet.

Far-sighted naturalists have long warned against this overexploitation. In 1786, the Portuguese explorer Alexandre Rodrigues Ferreira criticised the imprudent use of $P$. expansa in Brazilian Amazonia, particularly the wasteful capture of hatchlings for food and the depredation of nests for the production of turtle oil. In 1799, Alexander von Humboldt observed similar destructive exploitation in the Orinoco. Some 5000 jars of oil were harvested annually at just three major nesting beaches in this river. A jar contained 25 bottles and a bottle the contents of some 200 eggs. Humboldt calculated that if each turtle laid between 100 and 116 eggs, 330,000 females would have to lay some $33,000,000$ eggs to fill the 5000 jars of oil. Humboldt's clutch estimate may have been too high; recent studies show that the average clutch varies between 75 in the Rio Trombetas in Brazil ${ }^{19}$ and $82-86$ in the Orinoco. ${ }^{14}$ But even on Humboldt's calculations $33,000,000$ eggs would represent the output of more than 400,000 females.

The 19th-century English explorer-naturalist Henry Walter Bates made similar observations in Brazilian Amazonia:

The destruction of turtle eggs every year by these proceedings is enormous. At least 6,000 jars, holding each three gallons of the oil, are exported annually from the Upper Amazons and the Madeira to Pará, where it is used for lighting, frying fish, and other purposes. It may be fairly estimated that 2,000 more jar-fulls are consumed by the inhabitants of the villages on the river. Now it takes at least twelve basketsful of eggs, or about 6,000 , by the wasteful process followed, to make one jar of oil. The total number of eggs annually destroyed amounts, therefore, to $48,000,000$. As each turtle lays about 120 , it follows that the yearly offspring of 400,000 is thus annihilated. ${ }^{1}$

Bates's clutch estimate may also have been high. Using present-day estimates this figure for females losing offspring would be nearer 600,000 . It is possible that the turtle populations observed by Humboldt and Bates averaged slightly larger than today's populations and also produced larger egg clutches. However, Humboldt himself writes, 'The results of these calculations are much below the truth. Many tortoises lay only sixty or seventy eggs ...' 
Silva Coutinho (1868), a Brazilian naturalist of the last century whose ideas were well ahead of their time, recommended the prohibition of commercial oil exploitation. He also suggested the establishment of breeding areas where eggs could be deposited and the hatchlings protected.

In 1971 Ojasti presented some sobering figures for $P$. expansa in the Orinoco. ${ }^{12}$ He pointed out that where Humboldt estimated 330,000 animals in 1799 and 1800, Mosqueira Manso (1945) estimated only 123,600, Ramirez only 36,100 in 1950, and Ojasti himself 13,800 in 1965.

In Brazil, Venezuela, Colombia and Peru Podocnemis turtles are now nominally protected by law. The Venezuelans prohibited egg exploitation in 1946 and also limited the number of adult females that could be taken. Since 1962 , the major Venezuelan $P$. expansa beaches have been completely protected. ${ }^{12}$ Since 1965 Brazil has effectively protected three important beaches in the Rio Trombetas and two minor beaches in the Rio Tapajós. But these are the exceptions. There is little or no enforcement of protective legislation elsewhere in Amazonia and exploitation continues.

The Upper Amazon region of Brazil is a prime example. In areas where Bates found $P$. expansa to be common 120 years ago it is now very rare. As it disappeared, pressure shifted to the smaller species, with the result that they too are becoming rare - another example of what might be called the 'whaling syndrome'. In several of the medium-sized Upper Amazonian towns - Coari, Tefé, Fonte Boa, Codajás - boatloads of nesting $P$. unifilis females are brought in from previously little-touched beaches in the Rio Juruá and Rio Purús. Nests of the few females that are able to lay before being captured are emptied. If such exploitation is not rapidly curtailed, the breeding stock for the future will disappear.

Fortunately, the Brazilian government realises this and is trying to improve protection in the Upper Amazon. The Ministry of Agriculture and its branch, the Brazilian Forestry Development Institute (IBDF), are surveying a number of river systems to find the major remaining turtle beaches. Once located, effective protection measures, like those in the Tapajós and Trombetas, will it is hoped be decreed and enforced. Venezuela continues to protect its major beaches, and Colombia and Peru are beginning to show interest. But a great deal remains to be done. The key lies in complete protection of nesting females and eggs, at least until populations have built up again, coupled with detailed studies on behaviour and ecology to determine cropping rates for each species and how maximum production and survival of offspring can be ensured.

The next 10-20 years will tell whether the Podocnemis turtles will again take their place as a major resource in Amazonia or vanish for ever. Perhaps it will be possible to organise a Pan-Amazonian international programme devoted to the conservation and rational utilisation of the Podocnemis turtles. For what is needed now is large-scale cooperation at international, national and local levels, involving governments, biologists, conservationists, businessmen and the Amazonian people themselves.

\section{Acknowledgments}

The author would like to thank the New York Zoological Society for financing the Amazonian survey during which much of the material discussed in this paper was collected, and the Fundação de Amparo à Pesquisa do Estado de São Paulo (FAPESP) for use of the Expedição Permanente da Amazonia (EPA) boats in which the survey was conducted. P. E. Vanzolini and the EPA crew provided useful information on 
Amazonian turtles and J. Alfinito, M. M. Ferreira da Silva, C. Martins Vianna and R. C. Valle of the Ministero da Agricultura in Belem, Pará, were also very helpful during the study. Thanks go also to the following people for reading and commenting on earlier drafts of this paper: A. F. Coimbra-Filho, J. Fleagle, F. Wayne King, H. de Macedo-Ruiz, F. Medem, P. C. H. Pritchard, A. G. J. Rhodin, T. R. Roberts, N. J. H. Smith and N. Smythe.

All photos are by the author, except $\mathrm{P}$. dumeriliana and $\mathrm{P}$. vogli on $p .227$, which are courtesy of Instituto Roberto Franco.

\section{Literature Cited}

1. ALARCON PARDO, H. 1969. Contribución al conocimiento de la morfología, ecología y distribución geográfica de Podocnemis vogli, Testudinata (Pelomedusidae). Rev. Acad. Colomb. Cien. Ex. Fis. Nat. 13(51): 303-329.

2. BATES, H.W. 1863. The naturalist on the River Amazon. John Murray, London.

3. BELKIN, D.A. 1965. Reduction of metabolic rate in response to starvation in the turtle Sternothaerus minor. Copeia 1965 (3): 367-368.

4. CRAWFORD, M.A. 1974. The case for new domestic animals. Oryx 12(3): $351-360$.

5. FERREIRA, A.R. 1972. Viagem filosófica pelas Capitanias do Grão-Para, Rio Negro, Mato Grosso e Cuiabá. Conselho Federal de Cultura, Rio de Janeiro, $246 \mathrm{pp}$. (Reprint edition).

6. GRZIMEK, B. 1964. Rhinos belong to everybody. Collins, London.

7. HUMBOLDT, A. von 1859-1860. Reise in die Aequinoctial-Gegenden des neuen Continents. Vol. 3, Hermann Hauff, J. G. Cotta'scher Verlag, Stuttgart, 403 pp.

8. MEGGERS, B.J. 1971. Amazonia, man and culture in a counterfeit paradise. Aldine-Atherton, Chicago, viii + $182 \mathrm{pp}$.

9. MOSQUEIRA MANSO, J.M. 1945. Las tortugas del Orinoco. Ensayos biológicos de la arrau (Podocnemis expansa). III Conf. Interamer. Agric. Cuad. Verdes 29: 43 pp.

10. MITTERMEIER, R.A. and R.A. WILSON 1974. Redescription of Podocnemis erythrocephala (Spix, 1824), an Amazonian pelomedusid turtle. Papeis Avul. Zool., S. Paulo 28(8): 147-162.

11. OJASTI, J. 1967. Consideraciones sobre la ecologia y conservación de la tortuga Podocnemis expansa (Chelonia, Pelomedusidae). Atas Simp. Biota Amaz. 7: 201-206.

12. OJASTI, J. 1971. La tortuga arrau del Orinoco. Def. Naturaleza 1(2): $3-9$.

13. RAMIREZ, E. 1956. La tortuga, estudio biológico de la tortuga 'arrau' del Orinoco, Venezuela. Agricultor Venez. 21(190): 44-63.

14. ROZE, J.A. 1964. Pilgrim of the River. Nat. Hist. 73(7): 35-41.

15. SMITH, N. 1974a. Agouti and babassu. Oryx 12(5): 581-582.

16. - 1974b. Destructive exploitation of the South American river turtle Podocnemis expansa. Yearb. Assoc. Pacific Coast Geog. 36: 85-100.

17. TALBOT, L. 1963. Comparison of the efficiency of wild animals and domestic livestock in utilization of East African rangelands. In: Conservation of nature and natural resources in modern African states, CCTA/IUCN Symposium, Arusha, Tanganyika, September, 1961, IUCN Publ. (N.S.) 1.

18. TEMPLETON, J.R. 1970. Reptiles. In: Whittow, G.C., ed., Comparative physiology of thermoregulation, Vol. I. Academic Press, N.Y., 167-221.

19. VALLE, R.C., J. ALFINITO, and M.M. FERREIRA DA SILVA 1973. Contribuição ao estudo da tartaruga amazônica. In: Preservacão da tartaruga amazonica. Brazil. Ministerio da Agricultura, Directoria Estadual no Para,. 66-88.

20. WOOD, R.C. 1970. The fossil Pelomedusidae of Africa. Unpubl. doctoral dissertation, Harvard Univ.

Russell A. Mittermeier, New York Zoological Society, Bronx Zoo, Bronx, N.Y. 10460, USA; and Department of Anatomical Sciences, Health Sciences Center, State University of New York, Stony Brook, N.Y. 11794 , USA. 